\title{
CHILDREN FOSTER CARE LAW AND PRACTICE: WHAT MALAYSIA CAN LEARN FROM FOSTER CARE (IHTIDHAN) IN JORDAN*
}

\author{
Azizah Mohd** \\ Nadhilah A. Kadir***
}

\begin{abstract}
Foster care is one of the means of child protection in Malaysia and in many other countries like Singapore, Australia, United Kingdom, Algeria, Egypt and Morocco. This is also highlighted in international legal documents like the United Nations Convention of the Rights of the Child (the CRC) which also recognises the Islamic law concept of foster care (kaffalah). Through foster care, a child is placed either in an institution or fostered by individual foster parents. This paper aims at examining the law and practice of individual foster care in Malaysia with a comparative overview of the law and practice in Jordan. The comparison is intended to assist development of better law and practice of foster care in Malaysia where suitable, relevant and necessary.
\end{abstract}

\footnotetext{
* Part of this article was presented in International Conference on Law and Society, Yogyakarta, 15-18 February 2013. This research was funded by Ministry of Education, Government of Malaysia. Associate Professor of Law, Islamic Law Department, Ahmad Ibrahim Kulliyyah of Laws, International Islamic University Malaysia.

*** $\quad$ PhD Student, Islamic law Department, Ahmad Ibrahim Kulliyyah of Laws, International Islamic University Malaysia.
} 
The analysis focuses on certain suitable laws and practice of foster care in Jordan i.e. what Malaysia can learn from foster care in Jordan. The research is basically library research. A minor part of the research also involves interviews with the relevant officers on practices that are not documented. It is hoped that this paper will provide good suggestions for better protection of children in Malaysia through foster care.

Keywords: foster care, kaffalah, ihtidhan, Malaysian law, Jordanian law

\title{
UNDANG-UNDANG PEMELIHARAAN ANAK DAN AMALANNYA: APA YANG MALAYSIA BOLEH PELAJARI DARI PENJAGAAN ANAK PELIHARA DI JORDAN
}

\begin{abstract}
ABSTRAK
Penjagaan anak pelihara adalah salah satu kaedah perlindungan kanak-kanak di Malaysia dan di banyak negara lain seperti Singapura, Australia, Kerajaan Bersatu, Algeria, Mesir dan Maghribi. Perkara ini juga diserlahkan dalam dokumen undang-undang antarabangsa seperti Konvensyen Hak Kanak-kanak Pertubuhan Bangsa-bangsa Bersatu (CRC) yang turut mengiktiraf konsep penjagaan anak pelihara Islami (kaffalah). Menerusi penjagaan anak pelihara, seorang kanak-kanak diletakkan sama ada dalam sebuah institusi atau dijaga oleh ibu bapa penjaga persendirian. Makalah ini berhasrat untuk meneliti undang-undang dan amalan penjagaan anak pelihara persendirian di Malaysia dengan suatu ringkasan undang-undang dan amalan di Jordan. Perbandingan ini diniatkan untuk membantu perkembangan undangundang dan amalan penjagaan anak pelihara yang lebih baik di Malaysia pada perkara yang sesuai, berkaitan dan perlu. Analisis memfokuskan pada
\end{abstract}


sebahagian undang-undang dan amalan penjagaan anak pelihara di Jordan yang sesuai, iaitu apa yang Malaysia boleh pelajari dari penjagaan anak angkat di Jordan. Penyelidikan ini secara asasnya penyelidikan perpustakaan. Sebahagian kecil penyelidikan ini membabitkan temubual dengan pegawai berkaitan tentang sebahagian amalan yang tidak didokumenkan. Diharap makalah ini akan memberikan cadangancadangan yang baik untuk perlindungan yang lebih baik bagi kanak-kanakdi Malaysia menerusi penjagaan anak pelihara.

Kata Kunci: penjagaan anak angkat, kaffalah, ihtidhan, undangundang Malaysia, undang-undang Jordan

\section{INTRODUCTION}

Foster care in general refers to placement of a child in the care of a person(s) other than his biological parent(s). Such person is known as foster parent(s) who are willing to look after the child in their own homes for a short or long period. Foster care is one of the means to protect children in need of care and protection, especially those without families as well as those who have been abandoned, abused and neglected. Foster care becomes necessary when the biological parents are non-existent, or the family has significant problems of social, emotional, economic or physical nature. ${ }^{1}$ Basically, the primary purpose of foster care in many countries is to provide substitute care for children who have been abandoned, abused and/ or neglected so that they would have similar opportunities like other ordinary children. ${ }^{2}$ Substitute care is intended to substitute parental

$1 \quad$ Stahl, P.M., Children on Consignment: A Handbook for Parenting Foster Children and Their Special Needs, (Lexington Books, 1990), 4.

2 Colton, M., and Williams, M., "Global Trends in Foster Care" in Child Welfare:Major Themes in Health and Social Welfare Vol. III edited by Frost, N., Routledge, 3(2005):148. 
care, either partially or fully and it is considered as the main child welfare service. ${ }^{3}$

\section{FOSTER CARE IN MALAYSIA}

Foster care is commonly practised in Malaysia apart from adoption. Currently, there is no specific legislation governing foster care in Malaysia. The main law is the Child Act 2001 (the CA 2001). ${ }^{4}$ This Act is of general application and governs both, Muslims and non-Muslims. ${ }^{5}$ Foster care in Malaysia is based on the practice of the Social Welfare Department (SWD).

The CA 2001 defines 'foster parent' as a person who is taking care of the child, but is not a biological parent or relative of the child. ${ }^{6}$ Based on the practice of the Social Welfare Department, foster care has been defined as a placement of a child in the care, custody and control of foster parents under section 30(1)(e) of the CA 2001. ${ }^{7}$

Foster care in Malaysia is often a prerequisite before a person can adopt a child. ${ }^{8}$ It is termed as a fostering period which is also known as probationary period to allow a foster child and foster parents to become familiar with and fond of, each other, before an adoption order is made. ${ }^{9}$ For example, in child abandonment cases, the Malaysian court may make an order for a child to be adopted after two years in the care, custody and control of foster parents. ${ }^{10}$ The Adoption Act 1952 (the AA) also provides that an adoption order shall not be made until the period of fostering of three months, has

3 "child wefare", The Encyclopedia Americana, International Edition, Vol.6, (Grolier Incorporated, 1982), 463.

$4 \quad$ Act 611 .

$5 \quad$ See Child Act 2001, Section1.

$6 \quad$ Child Act 2001, Section 2.

7 Interview conducted by the author with Nizam Kassim, Assistant Director, Children's Division, Social Welfare Department of Malaysia, on 23 February 2011.

$8 \quad$ The New Encyclopaedia Britannica, n. 14. See also Rozario, B., "The Road to Adoption", http://parenthots.com.my/features/The-road-toadoption.aspx (viewed on Feb 25, 2010).

$9 \quad$ T.P.C v A.B.U \& Anor [1983] 2 MLJ 79 at 82.

$10 \quad$ Child Act 2001, section 30(4). 
lapsed. ${ }^{11}$ Alternatively, under the Registration of Adoptions Act 1952 (the RAA), the registration of de facto adoption can only be made after the child has been in custody of, brought up and maintained by the foster parents for a period of two years. ${ }^{12}$ During this period, the foster parents will cater for all the child's needs such as accommodation, feeding and clothing. After the period of fostering has lapsed, the foster child can be adopted legally.

\section{INDIVIDUAL FOSTER CARE}

Individual foster care is also known as family foster care since parents who are generally not professionally trained will act as foster parents and will look after the child in their own home. ${ }^{13}$ Basically, a foster family's responsibility is to provide twenty-four hour nurturing care to the foster child. ${ }^{14}$ They have a responsibility to provide food, pleasurable activities, warmth and a sense of belonging to a family as well as to develop a supportive foster care home environment where the child can feel at home in the family and becomes part of that family. ${ }^{15}$

Before the enactment of the CA 2001, a fostering system had been introduced by the SWD in placing an abandoned child with foster parents; however it is not easy to find a foster family who is willing to look after the child. ${ }^{16}$ Child abandonment cases are a common problem faced by the Malaysian government and it is not a new phenomenon. Generally, in these cases the children are placed in the care of suitable foster parents before the natural parents can be traced. This is because the SWD is of the opinion that it is best for the children to grow up and be nurtured in a family environment

\footnotetext{
$11 \quad$ Adoption Act 1952, section 4(a).

12 Registration of Adoption Act 1952, section 6(1).

13 Carr, A., The Handbook of Child and Adolescent Clinical Psychology: A Contextual Approach, (Routledge, 2007), 1027.

14 Stahl, n. 1.

15 Ibid., at 11.

16 Mohd Sham Kassim, "Cases of Children Being Abandoned at the General Hospital" in Workshop Report on Runaways and Abandoned Children, jointly organised by Malaysian Council for Child Welfare, National Council of Social Welfare and Ministry of Social Welfare Services Malaysia, 11 and 12 November 1988, at 97.
} 
provided for by the foster family, even though the welfare institutions have all the facilities to look after the child. ${ }^{17}$ Furthermore, the essential consideration before a child can be placed in family foster care is the suitability of the prospective foster parents; this will be determined by the SWD in order to ensure that the child will not be neglected in the foster care placement. ${ }^{18}$

A child can also be fostered through consent from the natural or biological parents of the child who are willing to give their child up for adoption. ${ }^{19}$ Since the natural parents have consented to give the child up for adoption, foster care can take place within two years before the child can be formally adopted. Besides, in the process of fostering there will be no registration through law, except when the child is ready to be legally adopted after two years. Furthermore, the foster parents must have a letter of approval for the adoption by the biological parents of the child which is signed before the Commissioner for Oaths. They should also notify the SWD not later than a week after such taking. ${ }^{20}$ Failure to notify will make the person liable to punishment of fine or imprisonment. The SWD can give permission to such person to look after the child after being satisfied that it is in the best interest of the child to live with the family. ${ }^{21}$

Individual foster care can be either temporary or permanent. Temporary foster care refers to short term care. The CA 2001 provides that an abandoned child will be placed in care, custody and control of a foster parent, for a period of two years or until the child reaches eighteen years old, whichever is shorter. ${ }^{22}$ The efforts to find the parent or guardian of the child will continue while he is in foster care, and if

17 Mohamad Hussain, "Protection and Adaptation in the Society", in Workshop Report on Runaways and Abandoned Children, jointly organised by Malaysian Council for Child Welfare, National Council of Social Welfare and Ministry of Social Welfare Services Malaysia, 11 and 12 November 1988, at 122.

18 Ibid.

$19 \quad$ Nor Affizar Ibrahim, "Proses Pengangkatan Dipermudahkan", Berita Harian Online, 18 May 2010, http://www.bharian.com.my/bharian/ articles/Prosespengangkatandipermudahkan/Article(viewed on May $\underline{24}, 2010$ ).

$20 \quad$ Child Act 2001, section 35.

$21 \quad$ Child Act 2001, section 35, section 37.

$22 \quad$ Child Act 2001, section 30(1)(e) 
the efforts are unsuccessful, he is sent for adoption. ${ }^{23}$ The officer of the SWD will find suitable foster parents who, in the spirit of performing a good deed, is willing to provide love for the child on a short term basis, upon the understanding that it is not permanent. ${ }^{24}$ This is because after the end of such placement period, the foster child is expected to return to their natural parents. Besides, the CA 2001 allows natural parents to reclaim abandoned children before the period of two years has lapsed and they will have no rights over the child once the order is made by the court to free the child for adoption. ${ }^{25}$ Therefore, the foster child is looked after by the foster parents temporarily for at least two years before the court decides that the child can be given for adoption. Alternatively, if the foster parents do not intend to continue fostering after temporary foster care is arranged, they can return the child by reporting in person to the Protector and bring the child before the Protector who can place the child in a place of safety or shelter homes for children. ${ }^{26}$

Short term or temporary foster care can also be extended to permanent foster care, especially when the foster children are no longer able to return to or reunite with their natural parents. Permanent foster care is also known as long term foster care where the children will stay with the foster families from about two years or more or until they reach adulthood or eighteen years old. The CA 2001 also provides that abandoned children can be placed in care, custody and control of foster parents until they reach eighteen years old. ${ }^{27}$ Thus, the foster parent may prolong or extend fostering a child until the child reaches the age of majority. In the case of an abandoned child, foster parents have to decide whether to adopt or keep fostering the child if it is declared that he has no parent or guardian to look after him. This is because the court may make an order after two years to allow the foster child to be adopted. ${ }^{28}$

$23 \quad$ Mohamad Hussain, "Protection and Adaptation in the Society", in Workshop Report on Runaways and Abandoned Children, jointly organised by Malaysian Council for Child Welfare, National Council of Social Welfare and Ministry of Social Welfare Services Malaysia, 11 and 12 November 1988, at 120.

$24 \quad$ Ibid. at 122.

$25 \quad$ Child Act 2001, section 30(4).

$26 \quad$ Child Act 2001, section 30(3).

$27 \quad$ Child Act 2001, section 30(1) (e).

28 Child Act 2001, section 30(4). 
Furthermore, if foster parents and foster child have developed and maintained their relationship for more than a year, the transition and acceptance is easier when the foster parents decide to continue providing long term commitment. ${ }^{29}$ This is because normally, after several years, the child will be attached to the foster parents and they are considered to be his parents. Accordingly, it is a long term or permanent foster care if foster parents decide to keep fostering the child after the period of two years has lapsed.

\section{FOSTER CARE IN JORDAN: THE LAW AND PRACTICE}

Jordan is an Islamic country and many of her laws, especially those that govern Muslims are based on the Shari 'ah. ${ }^{30}$ These include the law and practice that governs protection of children. Given that, there is no law specifically enacted to protect children in Jordan, the practise is based on the provisions of the Convention on the Rights of the Child 1989 (the CRC) in so far as it is in line with the Shari' 'ah, and it is felt that the CRC is sufficient to provide guidelines for child protection in Jordan. Presently, Jordan is in the process of putting in place its law on child protection based on the spirit of the CRC. ${ }^{31}$

There is yet any statute to govern foster care in Jordan. At present, the practice of foster care in Jordan is based on Juvenile law and it's Amendment (Qanun al-Ahdath wa Ta'dilaatihi) $1968^{32}$ and Child Protection Rules 1972 (From Birth up to Eighteen Years old) (Nizam Ri'ayat al-Tufulah (min al-Wiladah hatta al-Thaminah 'Ashar

\footnotetext{
$29 \quad$ Stahl, n. 1 at 94.

30 This information is obtained based on an interview with Mdm Lara al-Bukarki, Head, Child Custodial Department (rais qism alihtidhan), Ministry of Social Development, Duwar Dakhiliyyah, Amman, Jordan 31/12/2012 / Monday - 11.00am.

31 This information is obtained based on the interview with Dr Hanan al-Daher, head Wahdah al-Tashri'at wa al-Ittifaqiyyah, Al-Majlis alWatani li Shu'un al-Usrah, Jabal Amman, Amman, Jordan, 21/1/2013 - Monday - 10.15 am. See also National Council for Family Affairs \& UNICEF, Children in Jordan, Situation Analysis 2006/2007, 99. Law No. 24.
} 
1972). ${ }^{33}$ In practice, foster care is one of the means of protection of children without families which include children who are exposed to violence; for example, abandoned and illegitimate children, children whose family has problems (e.g., family breakdown) and street children like child labourers, waste collectors and beggars. Juvenile Law 1968 among others define children in need of protection as those including these kinds of children. ${ }^{34}$ These children are protected through placement in welfare institutions, social security (kaffalah) as well as individual foster care or foster parenting (ihtidhan/kaffalah). ${ }^{35}$ Juvenile Law 1968 also provides, among others, the legal penalties applicable to foster parents for neglect of or causing harm to children under their care.$^{36}$ As to individual foster care, a child is placed with foster or alternative family which is basically known as Usrah alhadhinah or Usrah al-Badilah. ${ }^{37}$

Child Protection Rules No. 341972 (the 'CPR') defines fostering and alternative family as any family that is suitable other than the natural familywho is entrusted by the MinistryortheCourtforalimited orunlimited period of time to take care and protect a child under the age of eighteen years old and is in need of protection either temporarily or permanently. ${ }^{38}$ This provision implies that individual foster care in Jordan is similar to what is available in Malaysia i.e., of two types either permanently or temporarily. The foster family will be responsible for all the needs that are delivered by a normal family under the supervision and monitoring of the ministry, in taking care of the child's health, safety, welfare and education. The foster family will also have the rights as if they are the child's parents within the period specified by the ministry or the court. ${ }^{39}$ The Ministry will conduct a sufficient social investigation on the family,

\footnotetext{
$33 \quad$ Law No. 34.

$34 \quad$ See Juvenile Law 1968, No. 24, Art. 31.

35 This information is obtained based on the interview with Dr Hanan al-Daher, head Wahdah al-Tashri'at wa al-Ittifaqiyyah, Al-Majlis alWatani li Shu'un al-Usrah, Jabal Amman, Amman, Jordan. 21/1/2013 - Monday - 10.15 am. See Juvenile Law 1968, No. 24,Art. 23. This information is obtained based on the interview with Dr Hanan al-Daher, head Wahdah al-Tashri'at wa al-Ittifaqiyyah, Al-Majlis alWatani li Shu'un al-Usrah, Jabal Amman, Amman, Jordan. Child Protection Rules (Jordan) 1972, No. 34, sect. 2. Child Protection Rules (Jordan) 1972, No. 34, sect. 3.
} 
including the foster family, the alternative family or the natural family according to that seen as sufficient by the Minister or the Court that is sufficient to entrust the child under their care. No child will be accepted in the foster care institution before such investigation is carried out. ${ }^{40}$ The CPR also provides that the religion of the foster child and foster family must be similar. In the case where the child's religion is undetermined, he is assumed to be a Muslim. ${ }^{41}$ In practice, a child who is subject to foster parenting will not be given to a non-Muslim family. ${ }^{42}$

Foster families can also obtain regular monthly allowances from the National Aid Fund. Finally, the father or other provider of the child in institutional or foster care can request for the child to be returned to the family in case of changed circumstances. ${ }^{43}$ A more comprehensive Fostering bill is expected to be passed through Parliament after the approval of the draft of the Childhood Act. ${ }^{44}$

The practice of Individual Foster Care is also based on the practice, procedures and conditions set by the Ministry of Social Development. According to Lara al-Bukarki, ${ }^{45}$ there are two kinds of foster care in Jordan namely, institutional foster care and individual foster care. Individual foster care is commonly known as al-ihtidhan, where individuals may apply to the Ministry of Social Development to foster a baby, especially among children of unknown parenthood who are placed in a welfare institution. Procedures and conditions are expressed in the policy of fostering a baby of unknown parentage. This policy is particularly framed to provide service to couples who are unable to have babies. ${ }^{46}$ Individuals may apply to the Head of Social

\footnotetext{
$40 \quad$ Child Protection Rules (Jordan) 1972, No. 34, sect. 4 \& 6.

$41 \quad$ Child Protection Rules (Jordan) 1972, No. 34, sect. 5.

42 This information is obtained based on an interview with Mdm Lara al-Bukarki, Head, Child Custodial Department (rais qism alihtidhan), Ministry of Social Development, Duwar Dakhiliyyah, Amman, Jordan 31/12/2012 / Monday - 11.00am.

$43 \quad$ Child Protection Rules (Jordan) 1972, sect. 13.

44 National Council for Family Affairs \& UNICEF, Children in Jordan, Situation Analysis 2006/2007, p. 99.

45 Head, Child Custodial Department (rais qism al-ihtidhan), Ministry of Social Development, Duwar Dakhiliyyah, Amman, Jordan.

46 This information is obtained based on an interview with Mdm Lara alBukarki, Head, Child Custodial Department (rais qism al-ihtidhan), Ministry of Social Development, Duwar Dakhiliyyah, Amman,
} 
Development and Women Affairs or the Head of Family and Children at the Ministry to foster a baby. This is the only department that deals, provides and manages fostering services. For non-Jordanians, the application can be made to the Jordanian Embassy or consulate overseas. Before making the application, the applicants must refer to the head of Social Development and Women Affairs. The Ministry will conduct a social investigation on the status and condition of the foster family. After the completion of the social investigation and all the required documents and the conditions are complied with, the application will be submitted to the fostering division in the Ministry to obtain approval from the Minister. The applicants will have to wait for sometime for the decision. When the applicants' turn comes, and there is a suitable baby as specified by the applicant e.g., in terms of age, race, gender etc, for fostering, the applicants will be sent a letter inviting them to visit and the child in the welfare institution (Mua'ssasat Hussain). Finally, the applicants will get an order from the Juvenile Court surrendering the baby to the applicant for complete protection as an alternative family. There will be a follow up by the Ministry on fostering through a visit to the foster family's home to investigate on the suitability of the foster child living in that family. In case where the foster family is living outside Jordan (foreigners), the monitoring and follow up will be done by the Foreign Ministry through the Jordan Embassy overseas. ${ }^{47}$

In order for the application to succeed, the applicants must comply with certain conditions which include that they are Muslims and if they are converts, they have converted to Islam for five years already. The status of the applicants for both husband and wife in terms of social standing and responsibility, environment, awareness and cultural values must be suitable to foster the baby. The husband and wife must be in good terms and are a loving couple, and they must have been married for not less than five years old before the application. As regards the age of the applicants, the husband must be

Jordan 31/12/2012 / Monday - 11.00am. See also al-Mamlakat alUrduniyyah al-Hashimiyyah, Ministry of Social Development and Women Affairs, Making Social Policy in Fostering Children of Unknown Parentage for Alternative Family, Service Form, p. 1.

47 See al-Mamlakat al-Urduniyyah al-Hashimiyyah, Ministry of Social Development and Women Affairs, Making Social Policy in Fostering Children of Unknown Parentage for Alternative Family, Service Form, p. 1. 
of not less than thirty five years old and not exceeding fifty five years old, while the applicant wife must not be less than thirty years and does not exceed fifty years old. It is also a requirement that both husband and wife are not able to have a child, are in good health and able to take good care of the child. More importantly, they are able to provide sufficient protection for the baby in matters of upbringing, education and health. In addition, the monthly income of the foster family must not be less than 350 dinars. Finally, the foster family must inform the Ministry in writing should there be a change in their address, and if they want to move to another place, they should inform the ministry before the transfer ${ }^{48}$ In order to make sure that the foster child will be raised according to Islamic principles and that both the foster child and foster family may socialise in accordance with Islamic principles, the officer or social worker involved in the fostering process will advise the foster mother to breastfeed the child. The act of breastfeeding the baby would be treated as allowing the blood of the foster parents to flow into the baby's body and thus making the baby their own. ${ }^{49} \mathrm{~A}$ legal Islamic opinion (fatwa) on permissibility of hormone injections in order to stimulate breast milk secretion was recently made. The fatwa, among others, provides that a woman either married or unmarried may stimulate breast milk secretion through hormone injection, and this seems to encourage breastfeeding of foster children. ${ }^{50}$ It was reported that the number of children who are given for individual foster care through the Ministry of Social Development of Jordan since 1967 until the end of 2011 is $964 .{ }^{51}$

48 Wizarah al-Tanmiyyah al-Ijtima'iyyah, Head of Family, Fostering Division, p. 1.

49 This information is obtained through an interview with Mdm Aishah Qasrawi, Social Worker (Al-Ikhsa'i Al-Ijtima'i), Muassasah Husin Al-Ijtima'yyah, Ashrafiyyah, Amman, 2 ${ }^{\text {nd }}$ January 2013 / Wednesday ; 11.40am.

See Lujnah al-Ifta', Da'irah al-Fatwa al-'am, the Legal implication (Hukm) hormones injection to stimulate breast milk and matters relating to it, 19/9/2012, fatwa no. 2691.

51 See Ministry of Social Development, Jordan (Fostering (Department), Statistic on Number of Children who were given for Fostering family and alternative Family. 


\section{WHAT MALAYSIA CAN LEARN FROM FOSTER CARE IN JORDAN}

The above discussion reveals several distinctive features of foster care in Jordan that Malaysia can learn from. The first is that Jordan allows inter-country fostering. In this circumstance, Jordan will act as the sending country and a non-Jordanian may apply for individual foster care in Jordan. Nevertheless, a Jordanian is not allowed to foster a foreign child. It follows that if a foreign child is taken into Jordan, he or she will not be given nationality, but can stay in Jordan by virtue of a year's visa (Iqamah)..$^{52}$ On the other hand, all children who are found in Jordan as foundlings and who are of unknown parentage are recognised as being of Jordanian nationality even though their parents might not be Jordanians. ${ }^{53}$ This is another aspect of the law and practice in Jordan that appears to really protect the nationality of children.

It is also interesting to note that as compared to Malaysia which practises adoption as defined in western law, there is totally no adoption (tabanni) in Jordan as it adopts Islamic principles of Kaffalah which is recognised by the CRC. ${ }^{54}$ In this case, a family takes over the care of the child, but the child's name and family origin are not legally changed. The child does not have a right to inheritance from the foster family unless through a will or bequest. ${ }^{55}$ This practice seems to be more realistic and in line with the nature of human beings who are linked to his ancestors through blood or lineage. The practice also

52 This information is obtained based on an interview with Mdm Lara al-Bukarki, Head, Child Custodial Department (rais qism alihtidhan), Ministry of Social Development, Duwar Dakhiliyyah, Amman, Jordan 31/12/2012 / Monday - 11.00am.

53 This information is obtained based on an interview with Dr Hanan al-Daher, head Wahdah al-Tashri'at wa al-Ittifaqiyyah, Al-Majlis alWatani li Shu'un al-Usrah, Jabal Amman, Amman, Jordan 21/1/2013 - Monday - $10.15 \mathrm{am}$.

54 This information is obtained based on the interview with Dr Hanan al-Daher, head Wahdah al-Tashri'at wa al-Ittifaqiyyah, Al-Majlis alWatani li Shu'un al-Usrah, Jabal Amman, Amman, Jordan21/1/2013 - Monday - 10.15 am. See also National Council for Family Affairs \& UNICEF, Children in Jordan, Situation Analysis 2006/2007, p. 99.

55 National Council for Family Affairs \& UNICEF, Children in Jordan, Situation Analysis 2006/2007, p. 99. 
reveals the true identity of a person and is far from being made up like which happens in Malaysia. Furthermore, even though the law recognises adoption as defined by western law and is applicable only to non-Muslims, there are cases where an application to adopt was made under adoption that governs Muslims (similar to foster care in Jordan), especially by non-Muslim adoptive parents who do not want to affect their lineal status. ${ }^{56}$

In addition, the practice in Jordan that encourages breastfeeding of the foster baby by the foster mother is also good to follow. This may strengthen the bond between the foster child and his foster family.

\section{CONCLUSION}

Although there is no specific legislation on foster care in Malaysia, foster care is recognised and accepted as one of the alternative means of child protection services. Foster care can be arranged either by the SWD or NGOs for children in need of care and protection such as orphans as well as abandoned, abused and neglected children. The SWD provides individual foster care and foster care institutions on a temporary and permanent basis. One of the distinctive features of foster care in Malaysia is that a foster child's status can be changed to adopted child and this can be done through registration of the fostering into adoption through the Registration of Adoptions Act 1952. Registration of adoption will provide further protection to foster children. As regards the law and practise in Jordan, she does not have the concept of adoption but has laws allowing fostering that is in line with the Sharì'ah. This practice is further enhanced with the spirit of fosterage (breastfeeding/rada'ah) which encourages foster mothers to breastfeed their foster babies. In addition, there is inter country fostering, which is currently not available in Malaysia. Perhaps, it is timely for the Malaysian government to revise the law on adoption and search for a new dimension for adoption patterns in Malaysia.

$56 \quad$ See Re Loh Toh Met, Decd; Kong Lai Fong \& Ors v Loh Peng Heng [1961] MLJ 234. 